\title{
KARAKTERISTIK PENGERINGAN RUMPUT LAUT Ulva sp. DAN Sargassum sp.
}

\section{Drying Characteristics of Ulva sp. and Sargassum sp. Seaweeds}

\author{
Dwi Joko Prasetyo*, Tri Hadi Jatmiko, dan Crescentiana Dewi Poeloengasih \\ Balai Penelitian Teknologi Bahan Alam, Lembaga IImu Pengetahuan Indonesia, \\ Jalan Jogja-Wonosari KM 31,5, Gunungkidul, DI Yogyakarta, Indonesia \\ *Korespondensi Penulis: prasetyo_dwijoko@yahoo.co.id \\ Diterima: 12 Februari 2018; Direvisi: 19 Maret 2018; Disetujui: 23 April 2018
}

\begin{abstract}
ABSTRAK
Dalam penelitian ini karakteristik pengeringan dari rumput laut Ulva sp. dan Sargassum sp. telah dipelajari. Proses pengeringan dilakukan pada kondisi variasi suhu 40,50 , dan $60{ }^{\circ} \mathrm{C}$ di dalam alat pengering laboratorium. Laju pengeringan dievaluasi dengan empat model pengeringan lapis tipis, yakni Newton, Page, Two-Term, dan Midilli. Model yang paling sesuai ditentukan dari nilai sum square error (SSE) dan root mean square error (RMSE) terendah, serta nilai $r$ tertinggi. Laju pengeringan kedua rumput laut memperlihatkan adanya periode laju pengeringan menurun dan tidak ada periode laju pengeringan konstan pada pengeringan Ulva sp. dan Sargassum sp. Hasil menunjukkan bahwa laju pengeringan meningkat seiring peningkatan kadar air dan suhu, dan laju pengeringan menurun seiring dengan berjalannya waktu. Laju pengeringan tertinggi diperoleh pada suhu $60^{\circ} \mathrm{C}$ untuk Ulva sp. dan Sargassum sp. Hasil evaluasi menunjukkan bahwa model Midilli memiliki nilai SSE dan RMSE terendah, serta nilai $r$ tertinggi. Berdasarkan hasil tersebut model Midilli merupakan model yang paling sesuai untuk menggambarkan laju pengeringan Ulva sp. dan Sargassum sp.
\end{abstract}

KATA KUNCI: pengeringan, rumput laut, Ulva sp., Sargassum sp.

\begin{abstract}
In this project drying characteristic of Ulva sp. and Sargassum sp. were studied. Drying process was conducted using laboratory scale dryer at various temperatures (40, 50, and $60{ }^{\circ} \mathrm{C}$ ). Four different thin layer drying models, i.e., Newton, Page, Two-term and Midilli were used to evaluate the drying kinetics. The most appropriate model was determined based on the lowest value of sum square error (SSE) and root mean square error (RMSE), and the highest value of $r$. There was only decrease period and no constant drying period in drying rate of Ulva sp. and Sargassum sp. The results showed that drying rate increased as moisture content and temperature increased, while drying rate decreased as drying time increased. The highest drying rate was obtained at $60^{\circ} \mathrm{C}$ for Ulva sp. and Sargassum sp. The evaluation reveals that Midilli model has the lowest value of SSE and RMSE and the highest value of $r$ at all condition. Based on the results, it was found that Midilli model was the appropriate model to describe the drying rate of Ulva sp. and Sargassum sp.
\end{abstract}

KEYWORDS: drying, seaweed, Ulva sp., Sargassum sp.

\section{PENDAHULUAN}

Rumput laut Ulva sp. dan Sargassum sp. merupakan rumput laut yang banyak ditemukan di Pantai Sepanjang, Yogyakarta. Kedua jenis rumput laut tersebut banyak dimanfaatkan oleh masyarakat pesisir Pantai Sepanjang baik sebagai bahan pangan maupun komoditas perdagangan. Rumput laut hijau Ulva sp. memiliki berbagai manfaat, antara lain sebagai sumber zat warna (Haryatfrehni, Dewi, Meilianda, Rahmawati, \& Sari 2015), polisakarida ulvan (Robic, Sassi, \& Lahaye, 2008), serat (Yaich et al., 2011; Yaich et al., 2015) dan protein (Tabarsa, Rezaei, Ramezanpour, \& Waaland, 2012), serta sebagai sumber antioksidan (Kurniasih, Pramesti, \& Ridlo, 2014). Rumput laut coklat Sargassum sp. juga memiliki potensi yang luar biasa di samping merupakan sumber alginat yang dapat dimanfaatkan sebagai pengemulsi, 
penstabil dan pensuspensi (Kadi, 2005), serta sebagai sumber antioksidan (Norra, Aminah, \& Suri, 2016). Berbagai manfaat tersebut menyebabkan kedua rumput laut memiliki nilai ekonomis. Pada umumnya kedua jenis rumput laut ini mengalami blooming saat musim kemarau, sehingga banyak dipanen oleh masyarakat sekitar Pantai Sepanjang. Rumput laut yang telah dipanen kemudian dikeringkan untuk dijual kepada pengepul atau diolah sendiri. Rumput laut Ulva sp. telah diolah menjadi keripik ulva oleh masyarakat sekitar dan dapat juga diolah menjadi produk nori ulva (Zakaria, Priosoeryanto, Erniati, \& Sajida, 2017).

Pada umumnya proses pengeringan rumput laut di tingkat masyarakat dilakukan secara langsung di pantai dengan bantuan sinar matahari. Metode pengeringan ini merupakan metode pengeringan paling mudah dan paling murah, namun memerlukan waktu cukup lama, yaitu 3-5 hari tergantung intensitas sinar matahari (Djaeni, Sasongko, \& van Boxtel, 2013; Masduqi, Izzati, \& Prihastanti, 2014). Selain itu pengeringan dengan menggunakan metode penjemuran umumnya menghasilkan produk yang kurang higienis serta berkualitas rendah (Djaeni et al.; Gothandapani, Parvathi, \& Kennedy, 1997). Fudholi, Sopian, Othman, \& Ruslan (2014) melaporkan bahwa dengan metode pengeringan solar dryerproses pengeringan rumput laut merah dapat dipercepat menjadi 15 jam atau 2 hari saja. Suherman et al. (2018) juga melaporkan bahwa metode pengeringan dengan solar dryer memiliki efisiensi yang lebih tinggi daripada metode pengeringan dengan sinar matahari langsung.

Salah satu aspek penting dalam penentuan laju proses pengeringan adalah penggunaan pemodelan matematika proses pengeringan. Pemodelan matematika proses pengeringan memperlihatkan karakteristik dari proses pengeringan bahan tersebut. Evaluasi model pengeringan lapis tipis telah diterapkan pada berbagai jenis rumput laut seperti Eucheuma cottonii (Djaeni \& Sari, 2015; Fithriani, Assadad, \& Siregar, 2016), Ascophyllum nodosum (Kadam, Tiwari, \&O'Donnell, 2015), dan Himanthalia elongata (Gupta, Cox, \& Abu-Ghannam, 2011), namun belum pernah dilakukan pada rumput laut Ulva sp. dan Sargassum $\mathrm{sp}$. Oleh karena itu penelitian ini bertujuan untuk menginvestigasi model pengeringan yang sesuai untuk menggambarkan karakteristik pengeringan rumput laut Ulva sp. dan Sargassum sp.

\section{BAHAN DAN METODE}

\section{Bahan}

Bahan utama yang digunakan dalam penelitian ini adalah rumput laut Ulva sp. dan Sargassum sp. yang diperoleh dari Pantai Sepanjang, Gunungkidul, DI Yogyakarta. Waktu pengambilan sampel disesuaikan dengan masa panen rumput laut yang dilakukan oleh masyarakat sekitar Pantai Sepanjang. Ulva sp. diambil pada bulan November 2017 dan Sargassum sp. diambil pada bulan Januari 2018. Rumput laut diambil langsung dari laut, kemudian dicuci dengan air laut, disortasi, dan diletakkan pada wadah berisi air laut untuk menjaga kondisi rumput laut. Proses pengeringan dilakukan pada hari berikutnya.

Dalam proses pengeringan ini, alat-alat yang dipergunakan adalah oven skala laboratorium UF110

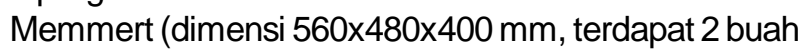

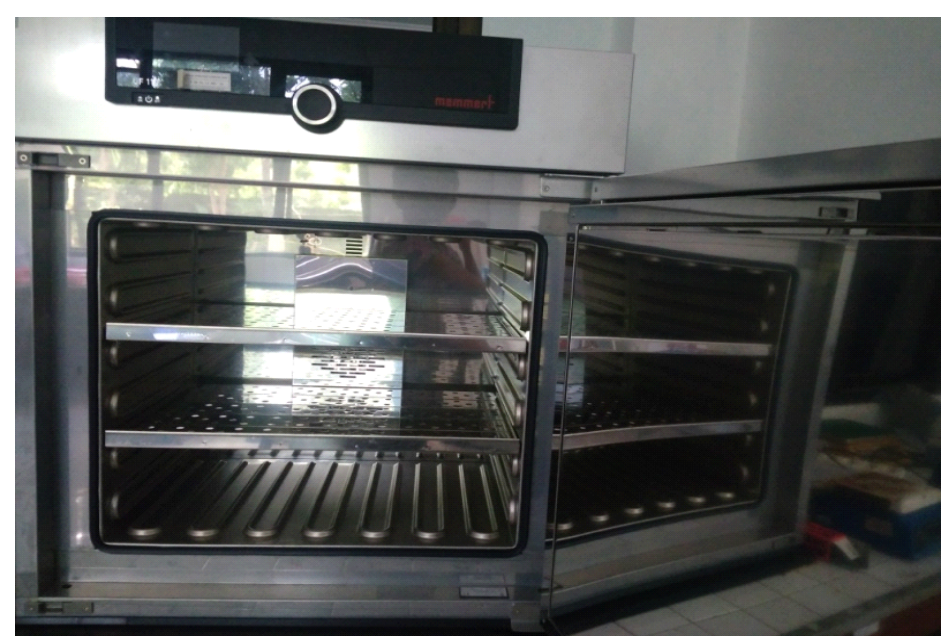

Gambar 1. Alat pengering skala laboratorium Figure1. Laboratory scale dryer 
rak), anemometer Sanfix GM8902, termohigrometer BioTemp, neraca analitis digital (AND GR-300), dan moisture analyzer (AND MX-50).

\section{Metode}

\section{Proses pengeringan}

Proses pengeringan dilakukan pada variasi suhu 40,50 , dan $60^{\circ} \mathrm{C}$ dengan sistem pengeringan udara tersirkulasi. Tiga level suhu tersebut dipilih karena pengeringan produk hasil pertanian dengan udara tersirkulasi disarankan dilakukan pada suhu $45-75^{\circ} \mathrm{C}$ (Fithriani et al., 2016). Variasi suhu 40,50 , dan $60^{\circ} \mathrm{C}$ juga telah diaplikasikan pada penelitian terdahulu tentang pengeringan rumput laut (Fithriani et al.; Fudholi et al., 2011). Pada setiap suhu percobaan kondisi oven diatur sama yakni pada kecepatan putaran kipas $50 \%$ dan bukaan flap $50 \%$, sehingga menghasilkan debit udara pengering pada nilai 0,209$0,238 \mathrm{~m}^{3} /$ menit. Massa rumput laut yang dikeringkan sebesar $600 \mathrm{~g}$ dan dibalik setiap $1 \mathrm{jam}$. Kelembaban udara relatif di dalam pengering selama proses pengeringan berada pada nilai $76-80 \%$, sedangkan kelembaban udara relatif udara sekitar berada pada nilai $82-86 \%$.

Parameter pengamatan dalam penelitian ini adalah:

a. Pengukuran perubahan massa sampel sebanyak $10 \mathrm{~g}$ dilakukan setiap 15 menit dengan 3 kali ulangan dan dihentikan setelah massa sampel bahan konstan. Pengukuran massa dilakukan dengan mengeluarkan sampel dari oven dan setelah dilakukan pengukuran, sampel dengan cepat dikembalikan ke dalam oven. Meskipun terdapat selisih antara kelembaban udara relatif di dalam oven (76-80\%) dan udara sekitar (82$86 \%$ ), pada kondisi ini diasumsikan laju adsorbsi uap air sekitar ke dalam bahan diabaikan karena fluktuasi nilai kelembaban relatif bukan merupakan faktor yang signifikan pada kecepatan pengeringan pada buah dan sayuran (Onwude, Hashim, Janius, Nawi, \& Abdan, 2016).

b. Pengukuran kadar air akhir/kadar air keseimbangan dari sampel dilakukan dengan alat moisture analyzer pada suhu operasi $105^{\circ} \mathrm{C}$.

c. Moisture ratio (MR) dihitung dengan persamaan berikut (Ibrahim, Sopian, \& Daud, 2009):

$M R=\frac{\text { MC-MCe }}{\text { MCO-MCe }}$
$M C=\frac{W w}{W d}$

\section{Keterangan:}

$$
\begin{array}{ll}
\text { MR } & =\text { Moisture ratio } \\
\text { MCe } & \text { kadar air keseimbangan, } \% \\
\text { MCO } & =\text { kadar air awal, } \% \\
\text { MC } & =\text { kadar air pada waktu tertentu, \% } \\
\text { Ww } & \text { = berat air yang teruapkan, gram } \\
\text { Wd } & =\text { berat kering, gram }
\end{array}
$$

d. Laju pengeringan pada tiap waktu dihitung dengan persamaan berikut:

$$
\mathrm{DR}=\frac{-\left(\mathrm{M}_{\mathrm{t}+\mathrm{d}}-\mathrm{M}_{\mathrm{t}}\right)}{\mathrm{dt}}
$$

\section{Keterangan:}
$\mathrm{DR} \quad=$ laju pengeringan, gram air/gram bahan kering/menit
$\mathrm{M}_{\mathrm{t}+\mathrm{dt}} \quad=$ kadar air pada waktu $\mathrm{t}+\mathrm{dt}$, gram air/gram bahan kering
$\mathrm{M}_{\mathrm{t}} \quad=$ kadar air pada waktut, gram air/gram bahan kering
dt $\quad=$ selisih waktu, menit

Nilai laju pengeringan total pada masing-masing rumput laut dan suhu ditentukan dengan persamaan di atas. Nilai laju pengeringan yang diperoleh kemudian diuji statistik. Ulva sp. dan Sargassum sp. merupakan dua jenis rumput laut dengan karakter yang sangat berbeda, sehingga uji statistik hanya dilakukan untuk melihat pengaruh suhu terhadap laju pengeringan. Uji statistik dilakukan dengan metode One Way Completely Randomized ANOVA menggunakan software CoStat untuk masing-masing rumput laut. Jika terdapat perbedaan signifikan, maka data diuji lanjut dengan Duncan Multiple Range Test (DMRT).

\section{Model matematika pengeringan}

Model matematika pengeringan Ulva sp. dan Sargassum sp. ditentukan dengan menggunakan data moisture ratio (MR) yang dihubungkan terhadap waktu,sehingga diperoleh kurva pengeringan. Kurva pengeringan kemudian dievaluasi menggunakan metode kuadrat terkecil (least square method) di Microsoft Excel dengan mencari nilai sum square error (SSE) terkecil. Kurva hasil evaluasi kemudian dicocokkan dengan empat model pengeringan lapis tipis. Model pengeringan yang dipilih adalah Newton, Page, Two-Term, dan Midilli. Model Newton dan Page merupakan model yang umum dipilih dalam evaluasi pengeringan rumput laut. Beberapa penelitian memperlihatkan bahwa model Page sesuai untuk evaluasi model pengeringan rumput laut (Djaeni \& Sari, 2015; Fithriani et al., 2016; Fudholi et al., 2011; Fudholi 
Tabel 1. Model pengeringan yang digunakan Table 1. Mathematical models used

\begin{tabular}{lcl}
\hline \multicolumn{1}{c}{ Model/Model } & Persamaan/Equation & \multicolumn{1}{c}{ Pustaka/Reference } \\
\hline Newton & MR $=\exp (-\mathrm{kt})$ & $\begin{array}{l}\text { Djaeni \& Sari, 2015; Fithriani et al., 2016; } \\
\text { Fudholi et. al., 2011; Fudholi et al., 2014 }\end{array}$ \\
Page & MR $=\exp \left(-\mathrm{kt}^{\mathrm{n}}\right)$ & $\begin{array}{l}\text { Djaeni \& Sari, 2015; Fithriani et al., 2016; } \\
\text { Fudholi et. al., 2011; Fudholi et al., 2014 }\end{array}$ \\
Two-term & $\mathrm{MR}=\mathrm{a} \exp (-\mathrm{kt})+\mathrm{a}_{1} \exp \left(-\mathrm{k}_{1} \mathrm{t}\right)$ & $\begin{array}{l}\text { Chin, et al., 2009; Ertekin \& Yaldiz, 2004; } \\
\text { Midilli, Kucuk, \& Yapar 2002 }\end{array}$ \\
Midilli & $\left.\mathrm{MR}=\mathrm{a} \exp \left(-\mathrm{kt}^{\mathrm{n}}\right)+\mathrm{a}_{1} \mathrm{t}\right)$ & $\begin{array}{l}\text { Chin, et al., 2009; Darvishi et. al., 2014; } \\
\text { Ertekin \& Yaldiz, 2004; Midilli et al., 2002 }\end{array}$ \\
\hline
\end{tabular}

et al., 2014). Model Two-Term dan Midilli sering dipilih untuk evaluasi komoditas lain dengan model Midilli menjadi model yang sesuai (Chin, Law, Supramanian, \& Cheng, 2009; Darvishi et al., 2014; Ertekin \& Yaldiz, 2004; Tulek, 2011). Di sisi lain keempat model yang dipilih memiliki karakteristik yang berbeda. Model Newton dan Page diturunkan berdasarkan Newton's Law of Cooling, sedangkan model Two-term dan Midilli berdasarkan Fick's Second Law of Diffusion (Erbay \& Icier, 2010). Oleh karena itu keempat model tersebut dikaji untuk melihat kesesuaian dengan proses pengeringan rumput laut, sehingga dapat diketahui karakteristik pengeringan rumput laut Ulva sp. dan Sargassum sp. Kurva yang terbentuk dari setiap model dievaluasi dengan root mean square error (RMSE) dan coefficent of correlation ( $r$ ). Model yang paling cocok adalah kurva dengan nilai $r$ tertinggi, serta nilai SSE dan RMSE terendah.

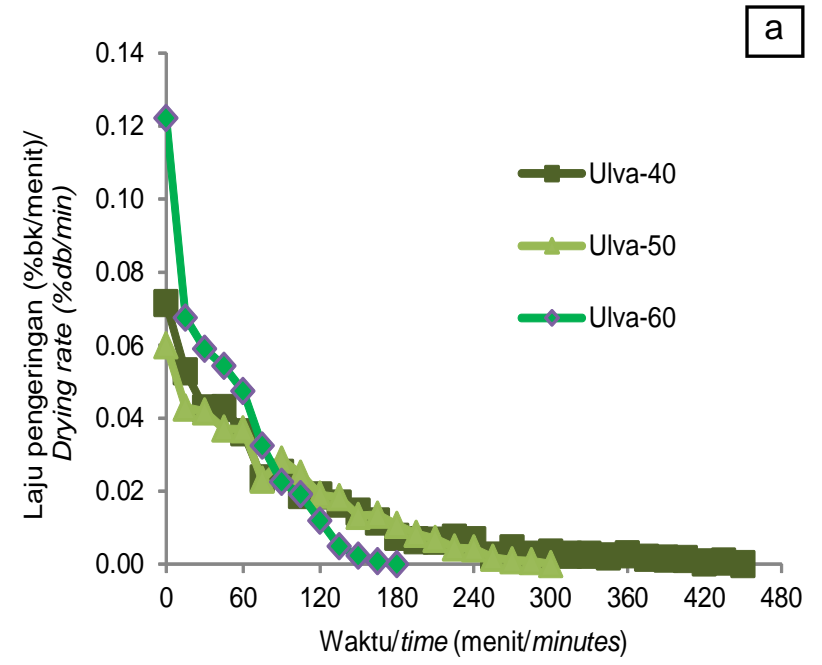

\section{HASIL DAN PEMBAHASAN}

\section{Pengaruh Waktu Pengeringan dan Kadar Air terhadap Laju Pengeringan}

Pengaruh waktu terhadap laju pengeringan Ulva sp. dan Sargassum sp. ditunjukkan pada Gambar 2. Laju pengeringan kedua rumput laut memperlihatkan fenomena yang sama, yakni didominasi oleh periode laju pengeringan menurun dan tidak adanya periode laju pengeringan konstan. Nilai laju pengeringan tertinggi diperoleh pada awal waktu pengeringan dan terus menurun sampai nilai terendah pada periode akhir pengeringan. Hasil ini sama untuk rumput laut Eucheuma cottonii (Fithriani et al., 2016) dan bahan lainnya (Darvishi et. al, 2014; Prasetyo, Jatmiko, Poeloengasih, \& Kismurtono, 2017; Tulek, 2011). Pada laju pengeringan menurun, mekanisme fisik berupa

Gambar 2.Hubungan antara waktu dan laju pengeringan Ulva sp. (a) dan Sargassum sp. (b)

Figure 2. Correlation between time and drying rate of Ulva sp. (a) and Sargassum sp. (b) 
difusi air di dalam bahan merupakan faktor yang dominan (Lahsasni, Kouhila, Mahrouz, \& Jaouhari, 2004).

Laju pengeringan kedua jenis rumput laut juga dipengaruhi oleh kadar air bahan seperti ditunjukkan pada Gambar 3. Penurunan nilai kadar air mengakibatkan penurunan nilai laju pengeringan (Prasetyo et al., 2017). Gambar 4 memperlihatkan penurunan kadar air bahan seiring dengan bertambahnya waktu dan hal ini menyebabkan penurunan nilai laju pengeringan. Nilai laju pengeringan tinggi terjadi pada awal waktu pengeringan. Hal ini disebabkan masih tingginya kadar air bebas di permukaan bahan, sehingga air lebih mudah teruapkan. Pada proses pengeringan Ulva sp. dan Sargassum sp. laju pengeringan konstan tidak terjadi, sehingga difusi merupakan mekanisme dominan pada proses pengeringan. Seiring bertambahnya waktu, air yang tersisa berada pada bagian dalam bahan, sehingga membutuhkan waktu untuk berdifusi menuju permukaan sebelum teruapkan. Hal ini yang menyebabkan semakin menurunnya laju pengeringan (Fithriani et al., 2016).

\section{Pengaruh Suhu terhadap Laju Pengeringan}

Nilai kadar air keseimbangan dan lama waktu pengeringan rumput laut Ulva sp. dan Sargassum sp. disajikan pada Tabel 2. Pada kedua jenis rumput laut terlihat bahwa kenaikan suhu pengeringan menyebabkan waktu pengeringan menjadi semakin singkat. Fenomena ini sama dengan hasil penelitian terdahulu pada rumput laut dan komoditas lain (Ertekin
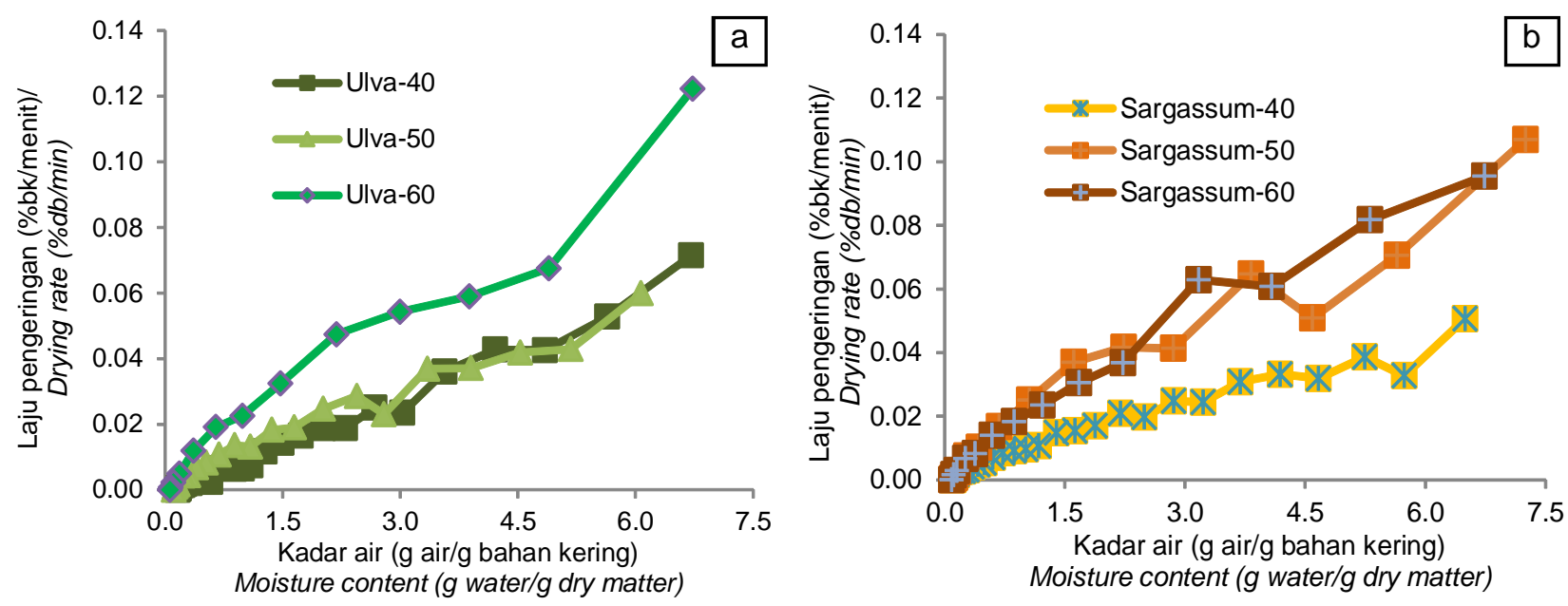

Gambar 3. Hubungan antara kadar air dan laju pengeringan Ulva sp. (a) Sargassum sp. (b) Figure 3. Correlation between moisture content and drying rate of Ulva sp. (a) Sargassum sp. (b)
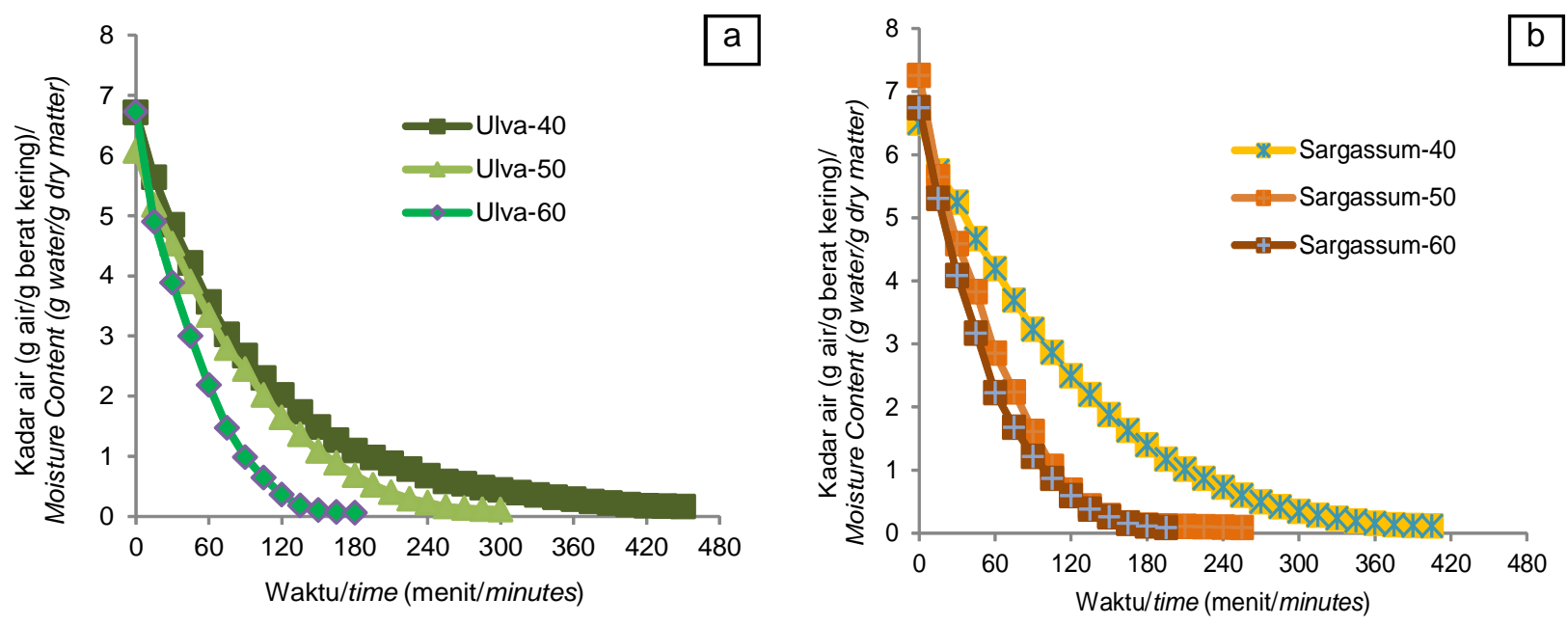

Gambar 4.Hubungan antara waktu dan kadar air Ulva sp. (a) Sargassum sp. (b) Figure 4. Correlation between time and moisture content of Ulva sp. (a) Sargassum sp. (b) 
Tabel 2. Kadar air keseimbangan dan waktu pengeringan rumput laut Ulva sp. dan Sargassum sp. Table 2. Equilibrium moisture contents and drying time of Ulva sp. and Sargassum sp. seaweeds

\begin{tabular}{|c|c|c|c|}
\hline $\begin{array}{l}\text { Rumput Laut/ } \\
\text { Seaweeds }\end{array}$ & $\begin{array}{c}\text { Suhu/ } \\
\text { Temperature }\left({ }^{\circ} \mathrm{C}\right)\end{array}$ & $\begin{array}{c}\text { Kadar Air Keseimbangan/ } \\
\text { Equilibrium Moisture } \\
\text { Content }(\%)\end{array}$ & $\begin{array}{c}\text { Waktu Pengeringan/ } \\
\text { Drying Time } \\
\text { (Menit/Minutes) } \\
\end{array}$ \\
\hline \multirow{3}{*}{$\begin{array}{l}\text { Ulva sp./ } \\
\text { Ulva sp. }\end{array}$} & 40 & 14.10 & 450 \\
\hline & 50 & 9.89 & 300 \\
\hline & 60 & 6.03 & 180 \\
\hline \multirow{3}{*}{$\begin{array}{l}\text { Sargassum sp./ } \\
\text { Sargassum sp. }\end{array}$} & 40 & 9.83 & 405 \\
\hline & 50 & 8.11 & 225 \\
\hline & 60 & 8.09 & 195 \\
\hline
\end{tabular}

\& Yaldiz, 2004; Gupta et al., 2011; Prasetyo et al., 2017). Pada suhu 40 dan $50{ }^{\circ} \mathrm{C}$, Ulva sp. membutuhkan waktu pengeringan lebih lama dan kadar air keseimbangan lebih tinggi dibandingkan dengan Sargassum sp., sedangkan pada suhu $60^{\circ} \mathrm{C}$ terjadi fenomena yang sebaliknya. Nilai kadar air keseimbangan berbagai suhu dari Ulva sp.memiliki rentang nilai yang lebih lebar $(6,03-14,10 \%)$ dibanding dengan Sargassum sp. (8,09-9,83\%). Pada kedua rumput laut terdapat fenomena yang sama, yakni kenaikan suhu menyebabkan penurunan kadar air keseimbangan bahan.

Laju pengeringan total pada masing-masing bahan dan variasi suhu pengeringan yang diperoleh kemudian dihitung dan dilakukan uji statistik yang hasilnya disajikan pada Tabel 3. Dari hasil uji statistik dapat diketahui bahwa pada kedua jenis rumput laut, suhu mempengaruhi nilai laju pengeringan $(p<0,05)$. Pengaruh suhu terhadap laju pengeringan diuji lebih lanjut dengan Duncan Multiple Range Test (DMRT). Hasil uji menunjukkan bahwa laju pengeringan tertinggi kedua rumput laut diperoleh pada suhu pengeringan $60{ }^{\circ} \mathrm{C}$. Hal ini sejalan dengan hasil penelitian yang dilakukan oleh Ertekin \& Yaldiz (2004) bahwa semakin tinggi suhu pengeringan, maka laju pengeringan akan semakin cepat. Pada suhu yang lebih tinggi, perbedaan suhu antara permukaan bahan dan udara pengering semakin besar. Hal ini memicu peningkatkan jumlah uap air yang teruapkan, sehingga laju pengeringan juga meningkat (Chin et al., 2009). Akan tetapi penggunaan suhu pengeringan yang terlalu tinggi tidak disarankan karena akan merusak komponen aktif pada bahan (Chin et al.; Fithriani et al., 2016; Tulek, 2011).

Laju pengeringan dipengaruhi oleh sifat bahan dan kondisi operasi pengeringan. Dalam penelitian ini kedua jenis rumput laut memiliki sifat yang berbeda. Ulva sp. memiliki bentuk seperti lembaran daun tipis, sedangkan rumput laut Sargassum sp. memiliki bentuk yang lebih tebal dan lebih komplek dengan adanya bentuk seperti batang dan daun. Hal ini menyebabkan penempatan Sargassum sp. di dalam oven menjadi lebih ringkas daripada Ulva sp., sehingga pada proses pengeringan Sargassum sp. udara panas dapat menjangkau seluruh permukaan bahan dibandingkan pengeringan pada Ulva sp. Oleh karena

Tabel 3. Laju pengeringan Ulva sp. dan Sargassum sp. pada berbagai Suhu Table 3. Drying rate of Ulva sp. and Sargassum sp. at various temperatures

\begin{tabular}{|c|c|c|}
\hline \multirow[t]{2}{*}{ Suhu/Temperature $\left({ }^{\circ} \mathrm{C}\right)$} & \multicolumn{2}{|c|}{$\begin{array}{c}\text { Laju Pengeringan/Drying Rate } \\
\text { ((Air/Berat Kering(g/g)/Menit/Water/Dry Matter (g/g)/Minutes)) }\end{array}$} \\
\hline & Ulva sp./Ulva sp. & Sargassum sp./Sargassum sp. \\
\hline 40 & $0.0145^{\mathrm{c}}$ & $0.0158^{\mathrm{C}}$ \\
\hline 50 & $0.0199^{b}$ & $0.0281^{b}$ \\
\hline 60 & $0.0370^{\mathrm{a}}$ & $0.0341^{a}$ \\
\hline
\end{tabular}

Keterangan/Note:

Huruf yang sama menunjukkan tidak beda nyata untuk kolom yang sama/The same letter shows no significant difference for the same column 

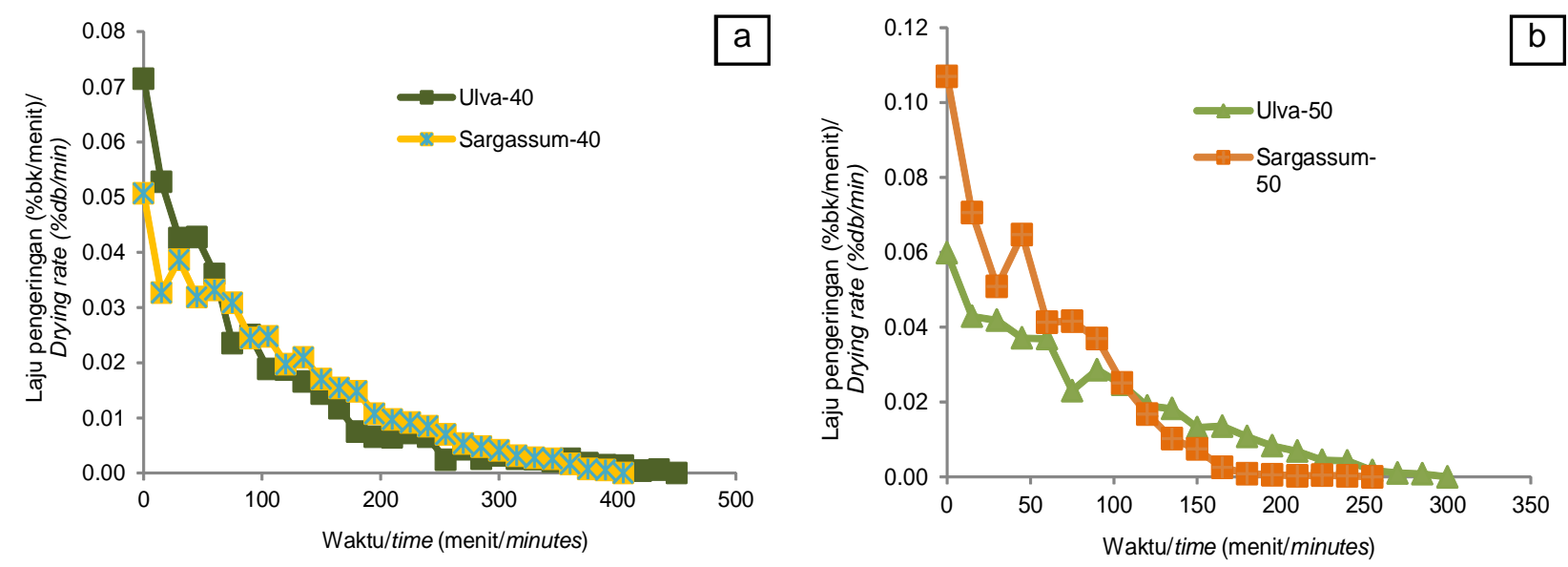

Gambar 5. Hubungan antara waktu dan laju pengeringan Ulva sp. dan Sargassum sp. pada suhu $40^{\circ} \mathrm{C}$ (a) dan $50^{\circ} \mathrm{C}(\mathrm{b})$

Figure 5. Correlation between time and drying rate of Ulva sp. and Sargassum $s p$. at temperature of $40^{\circ} \mathrm{C}$ (a) and $50^{\circ} \mathrm{C}$ (b)

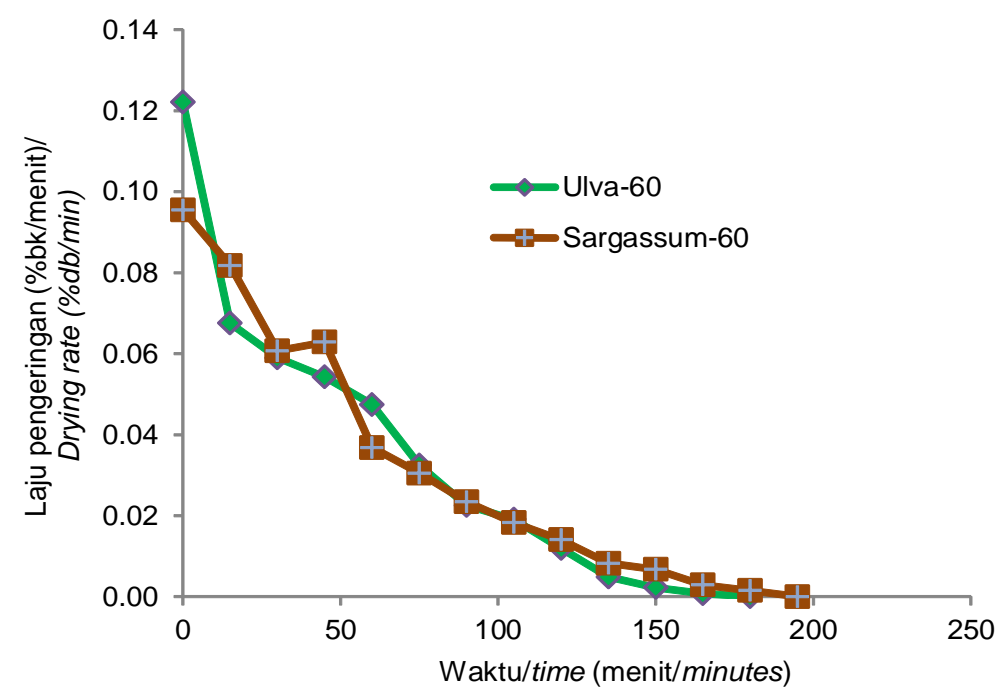

Gambar 6. Hubungan antara waktu dan laju pengeringan Ulva sp. dan Sargassum sp. pada suhu $60^{\circ} \mathrm{C}$

Figure 6. Correlation between time and drying rate of Ulva sp. and Sargassum $s p$. at temperature of $60^{\circ} \mathrm{C}$

itu, pada suhu 40 dan $50{ }^{\circ} \mathrm{C}$ waktu pengeringan Sargassum sp. lebih singkat dibandingkan Ulva sp. (Tabel 2).

Sebaliknya pada suhu pengeringan $60^{\circ} \mathrm{C}$, Ulva sp. memerlukan waktu pengeringan lebih singkat daripada Sargassum sp. Hasil penelitian menunjukkan tidak dijumpai adanya fase laju pengeringan konstan pada proses pengeringan Ulva sp. dan Sargassum sp. pada berbagai variasi suhu. Hal tersebut menunjukkan bahwa proses difusi merupakan mekanisme dominan yang terjadi selama proses pengeringan. Peningkatan kecepatan pengeringan Ulva sp. pada suhu $60^{\circ} \mathrm{C}$ menunjukkan adanya kemungkinan perubahan mekanisme yang terjadi selama proses pengeringan, sehingga pada suhu tersebut Ulva sp. lebih cepat kering dibandingkan Sargassum sp.

\section{Model Matematika Pengeringan Ulva sp. dan Sargassum sp.}

Korelasi antara nilai moisture ratio (MR) dan waktu disajikan pada Gambar 7. Kurva yang terbentuk kemudian dievaluasi dengan empat model pengeringan lapis tipis dan hasil evaluasi disajikan pada Tabel 4. Hasil evaluasi kurva pengeringan kedua jenis rumput pada berbagai variasi suhu memperlihatkan model 

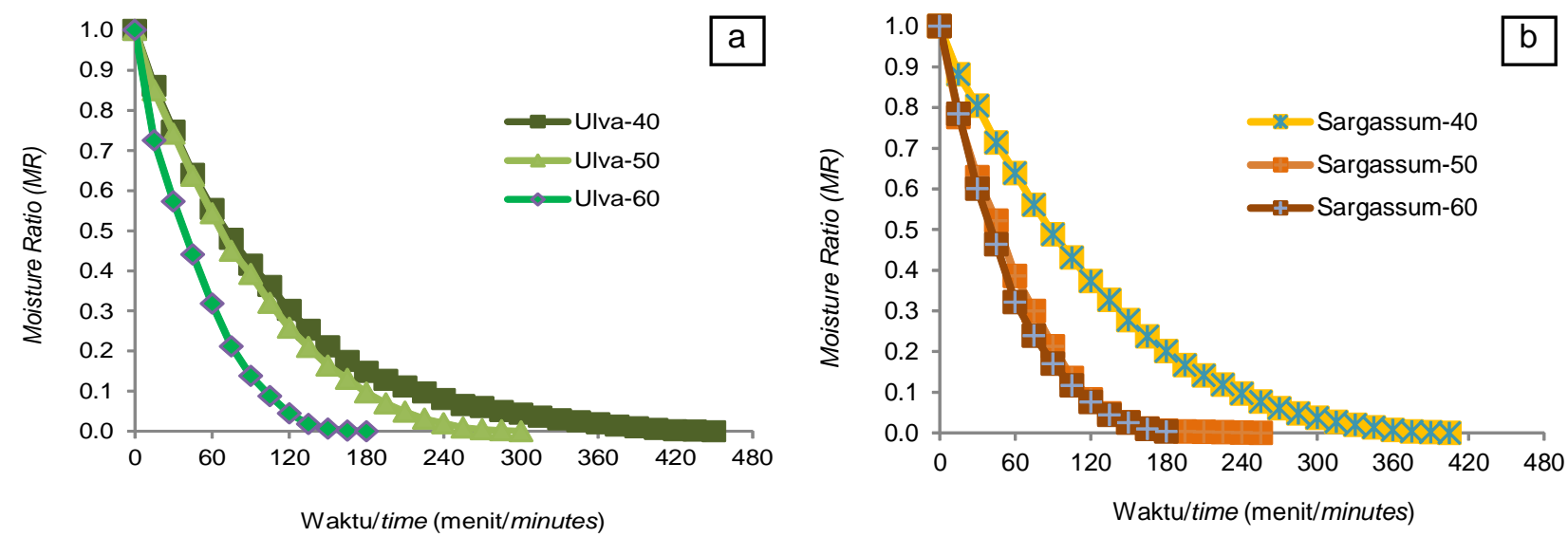

Gambar 7. Hubungan antara waktu dan MR Ulvasp. (a) Sargassum sp. (b)

Figure 7. Correlation between time and MR of Ulva sp. (a) Sargassum sp. (b)

Tabel 4. Evaluasi Model Matematika

Table 4. Mathematical Models Evaluation

\begin{tabular}{|c|c|c|c|c|c|c|c|c|c|}
\hline $\begin{array}{l}\text { Rumput Laut/ } \\
\text { Seaweeds }\end{array}$ & $\begin{array}{c}\text { Suhu/ } \\
\text { Temperature }\left({ }^{\circ} \mathrm{C}\right)\end{array}$ & $\begin{array}{c}\text { Model/ } \\
\text { Models }\end{array}$ & & $\begin{array}{l}\text { KoI } \\
\text { Co }\end{array}$ & $\begin{array}{l}\text { tanta/ } \\
\text { stants }\end{array}$ & & SSE & $r$ & RMSE \\
\hline \multirow{18}{*}{$\begin{array}{l}\text { Ulva sp./ } \\
\text { Ulva sp. }\end{array}$} & \multirow{6}{*}{40} & New ton & $\mathrm{k}=$ & 0.0102 & & & 0.0025 & 0.9997 & 0.0148 \\
\hline & & Page & $\mathrm{k}=$ & 0.0080 & $\mathrm{n}=$ & 1.0505 & 0.0010 & 0.9998 & 0.0083 \\
\hline & & Tw o-term & $a=$ & 1.0234 & $\mathrm{k}=$ & 0.0104 & 0.0018 & 0.9997 & 0.0147 \\
\hline & & & $\mathrm{a} 1=$ & -0.0234 & $\mathrm{k} 1=$ & 0.9987 & & & \\
\hline & & Midilli & $a=$ & 0.9955 & $\mathrm{n}=$ & 0.0082 & 0.0007 & 0.9999 & 0.0000 \\
\hline & & & $\mathrm{a} 1=$ & 0.0000 & $k=$ & 1.0410 & & & \\
\hline & \multirow{6}{*}{50} & New ton & $\bar{k}=$ & 0.0115 & & & 0.0212 & 0.9973 & 0.0344 \\
\hline & & Page & $\mathrm{k}=$ & 0.0048 & $\mathrm{n}=$ & 1.1876 & 0.0060 & 0.9986 & 0.0286 \\
\hline & & Tw o-term & $a=$ & 1.0783 & $\mathrm{k}=$ & 0.0124 & 0.0150 & 0.9969 & 0.0403 \\
\hline & & & $\mathrm{a} 1=$ & -0.0783 & $\mathrm{k} 1=$ & 0.9995 & & & \\
\hline & & Midilli & $a=$ & 0.9864 & $\mathrm{n}=$ & 0.0059 & 0.0017 & 0.9995 & 0.0007 \\
\hline & & & $\mathrm{a} 1=$ & -0.0001 & $\mathrm{k}=$ & 1.1237 & & & \\
\hline & \multirow{6}{*}{60} & New ton & $\mathrm{k}=$ & 0.0207 & & & 0.0117 & 0.9969 & 0.0318 \\
\hline & & Page & $k=$ & 0.0115 & $\mathrm{n}=$ & 1.1431 & 0.0065 & 0.9977 & 0.0260 \\
\hline & & Tw o-term & $a=$ & 1.0592 & $\mathrm{k}=$ & 0.0218 & 0.0102 & 0.9967 & 0.0322 \\
\hline & & & $\mathrm{a} 1=$ & -0.0592 & $\mathrm{k} 1=$ & 0.9999 & & & \\
\hline & & Midilli & $a=$ & 0.9889 & $\mathrm{n}=$ & 0.0146 & 0.0034 & 0.9987 & 0.0010 \\
\hline & & & $\mathrm{a} 1=$ & -0.0002 & $\mathrm{k}=$ & 1.0654 & & & \\
\hline \multirow{18}{*}{$\begin{array}{l}\text { Sargassum sp./ } \\
\text { Sargassum sp. }\end{array}$} & \multirow{6}{*}{40} & New ton & $\mathrm{k}=$ & 0.0087 & & & 0.0244 & 0.9977 & 0.0334 \\
\hline & & Page & $\mathrm{k}=$ & 0.0035 & $\mathrm{n}=$ & 1.1857 & 0.0047 & 0.9992 & 0.0255 \\
\hline & & Tw o-term & $a=$ & 1.0759 & $\mathrm{k}=$ & 0.0094 & 0.0160 & 0.9975 & 0.0407 \\
\hline & & & $\mathrm{a} 1=$ & -0.0759 & $\mathrm{k} 1=$ & 0.9987 & & & \\
\hline & & Midilli & $a=$ & 0.9845 & $\mathrm{n}=$ & 0.0039 & 0.0011 & 0.9998 & 0.0005 \\
\hline & & & $\mathrm{a} 1=$ & -0.0001 & $\mathrm{k}=$ & 1.1482 & & & \\
\hline & \multirow{6}{*}{50} & New ton & $\mathrm{k}=$ & 0.0174 & & & 0.0203 & 0.9962 & 0.0400 \\
\hline & & Page & $k=$ & 0.0072 & $\mathrm{n}=$ & 1.2039 & 0.0080 & 0.9978 & 0.0289 \\
\hline & & Tw o-term & $a=$ & 1.0898 & $\mathrm{k}=$ & 0.0188 & 0.0156 & 0.9961 & 0.0414 \\
\hline & & & $\mathrm{a} 1=$ & -0.0898 & $\mathrm{k} 1=$ & 0.9995 & & & \\
\hline & & Midilli & $a=$ & 0.9775 & $\mathrm{n}=$ & 0.0069 & 0.0059 & 0.9982 & 0.0026 \\
\hline & & & $\mathrm{a} 1=$ & -0.0001 & $\mathrm{k}=$ & 1.2021 & & & \\
\hline & \multirow{6}{*}{60} & New ton & $\mathrm{k}=$ & 0.0191 & & & 0.0096 & 0.9984 & 0.0237 \\
\hline & & Page & $\mathrm{k}=$ & 0.0092 & $\mathrm{n}=$ & 1.1753 & 0.0014 & 0.9995 & 0.0137 \\
\hline & & Tw o-term & $a=$ & 1.1073 & $\mathrm{k}=$ & 0.0210 & 0.0045 & 0.9987 & 0.0237 \\
\hline & & & $\mathrm{a} 1=$ & -0.1073 & $\mathrm{k} 1=$ & 0.9999 & & & \\
\hline & & Midilli & $a=$ & 0.9969 & $\mathrm{n}=$ & 0.0107 & 0.0005 & 0.9998 & 0.0003 \\
\hline & & & $\mathrm{a} 1=$ & -0.0001 & $\mathrm{k}=$ & 1.1285 & & & \\
\hline
\end{tabular}



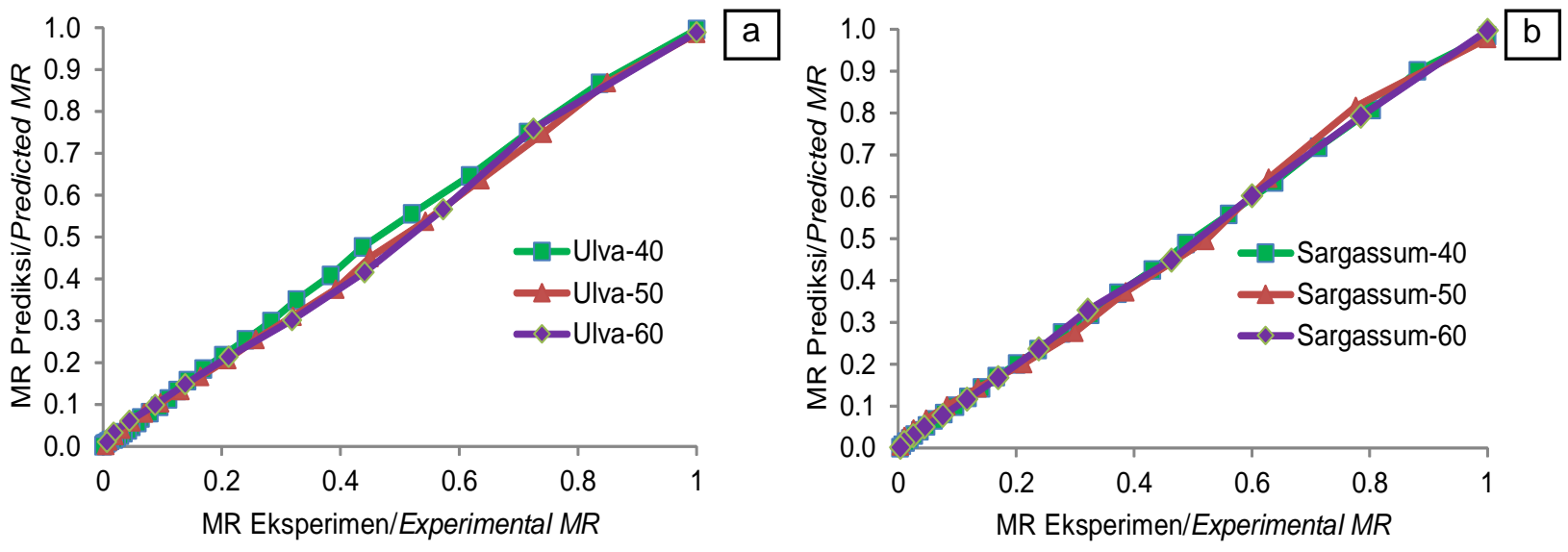

Gambar 8. Hubungan antara MR eksperimen dengan MR prediksi pada pengeringan Ulvasp. (a) dan Sargassum sp. (b) pada suhu 40,50 , dan $60^{\circ} \mathrm{C}$

Figure 8. Correlation between experimental MR and predicted MR of Ulva sp. (a) and Sargassum sp. (b) drying at temperature of 40,50 , and $60^{\circ} \mathrm{C}$

Midilli merupakan model yang paling sesuai. Pada berbagai kondisi pengeringan, model Midilli memiliki nilai SSE dan RMSE terendah dan nilai $r$ tertinggi. Perbandingan antara nilai MR hasil model dengan nilai MR eksperimen ditunjukkan pada nilai SSE, $r$, dan RMSE pada Tabel 4. Hasil ini menunjukkan bahwa proses pengeringan rumput laut Ulva sp. dan Sargassum sp. secara teoritis lebih cenderung mengikuti Fick's Second Law of Diffusion daripada Newton's Law of Cooling. Model Midilli lebih sering digunakan untuk evaluasi pengeringan komoditas lain dibanding dengan rumput laut, dan hasil ini sesuai dengan hasil terdahulu pada beberapa komoditas yang lain (Darvishi et al., 2014; Ertekin \& Yaldiz, 2004; Prasetyo et al., 2017; Tulek, 2011). Model lain yang kesesuaiannya mendekati model Midilli adalah model Page. Hal ini sesuai dengan hasil penelitian sebelumnya pada pengeringan berbagai jenis rumput laut (Djaeni \& Sari, 2015; Fithriani et al., 2016; Fudholi et al., 2011; Fudholi et al., 2014).

Penerapan dari evaluasi model pengeringan dapat digunakan untuk memprediksi nilai MR atau kandungan air bahan pada berbagai waktu pengeringan, sehingga proses pengeringan dapat dikendalikan dan diperoleh hasil sesuai yang diinginkan. Contoh aplikasi adalah seperti pada Gambar 8 yang memperlihatkan korelasi antara MR eksperimen dan MR prediksi pada pengeringan Ulva sp. dan Sargassum sp. pada suhu 40,50 , dan $60^{\circ} \mathrm{C}$. Indikasi bahwa model terpilih sesuai dengan hasil aktual ditunjukkan dengan sudut kurva yang mendekati nilai $45^{\circ} \mathrm{C}$ (Tulek, 2011).

\section{KESIMPULAN}

Laju pengeringan rumput laut Ulva sp. dan Sargassum sp. memiliki karakteristik laju pengeringan menurun dan tanpa laju pengeringan konstan. Laju pengeringan kedua bahan menurun seiring dengan bertambahnya waktu, dan berbanding lurus dengan kandungan air bahan dan suhu. Hasil evaluasi model matematika memperlihatkan bahwa model Midilli memiliki nilai SSE dan RMSE terendah, serta nilai $r$ tertinggi, sehingga model Midilli merupakan model yang paling sesuai untuk pengeringan kedua jenis rumput laut.

\section{DAFTAR PUSTAKA}

Chin, S. K., Law, C. L., Supramaniam, C. V., \& Cheng, P. G. (2009). Thin-Layer drying characteristics and quality evaluation of air-dried Ganoderma tsugae Murrill. Drying Technology, 27(9), 975-984. doi:10.1080/ 07373930902904350

Darvishi, H., Rezaie, A., Asghari, A., Azadbakht, M., Najafi, G., \& Khodaei, J. (2014). Study of the drying kinetics of pepper. Journal of the Saudi Society of Agricultural Sciences, 13(2), 130-138. doi:10.1016/ j.jssas.2013.03.002

Djaeni, M., \& Sari, D. A. (2015). Low Temperature Seaweed Drying Using Dehumidified Air. Procedia Environmental Sciences, 23(Ictcred 2014), 2-10. doi:10.1016/j.proenv.2015.01.002

Djaeni, M., Sasongko, S. B., \& Van Boxtel, A. J. B. (2013). Enhancement of Energy Efficiency and Food Product Quality Using Adsorption Dryer with Zeolite. International Journal of Renewable Energy 
Development, 2(2), 81-86. Retrieved from www.ijred.com

Erbay, Z., \& Icier, F. (2010). A review of thin layer drying of foods: Theory, modeling, and experimental results. Critical Reviews in Food Science and Nutrition, 50(5), 441-464. doi:10.1080/10408390802437063

Ertekin, C., \& Yaldiz, O. (2004). Drying of eggplant and selection of a suitable thin layer drying model, 63, 349-359. doi:10.1016/j.jfoodeng.2003.08.007

Fithriani, D., Assadad, L., \& Siregar, Z.A. (2016). Karakteristik dan Model Matematika Kurva Pengeringan Rumput Laut Eucheuma cottonii. Jurnal Pascapanen dan Bioteknologi Kelautan dan Perikanan, 11(2), 159-170. doi:10.15578/ jpbkp.v11i2.290

Fudholi, A., Othman, M. Y., Ruslan, M. H., Yahya, M., Zaharim, A., \& Sopian, K. (2011). The effects of drying air temperature and humidity on drying kinetics of seaweed. Recent Research in Geography, Geology, Energy, Environment and Biomedicine, Corfu, 129133.

Fudholi, A., Sopian, K., Othman, M. Y., \& Ruslan, M. H. (2014). Energy and exergy analyses of solar drying system of red seaweed. Energy and Buildings, 68(PARTA), 121-129. doi:10.1016/ j.enbuild.2013.07.072

Gothandapani, L., Parvathi, K., \& Kennedy, Z. J. (1997). Evaluation of Different Methods of Drying on the Quality of Oyster Mushroom (Pleurotus sp.). Drying Technology 15(6-8), 1995-2004. doi:10.1080/ 07373939708917344

Gupta, S., Cox, S., \& Abu-Ghannam, N. (2011). Effect of different drying temperatures on the moisture and phytochemical constituents of edible Irish brown seaweed. LWT - Food Science and Technology, 44(5), 1266-1272. doi:10.1016/j.Iwt.2010.12.022

Haryatfrehni, R., Dewi, S.C., Meilianda, A., Rahmawati, S., \& Sari, I.Z.R. (2015). Preliminary Study the Potency of Macroalgae in Yogyakarta: Extraction and Analysis of Algal Pigments from CommonGunungkidul Seaweeds. Procedia Chemistry, 14, 373-380. doi:10.1016/j.proche.2015.03.051

Ibrahim, M., Sopian, K., \& Daud, W. R. W. (2009). Study of the Drying Kinetics of Lemon Grass. American Journal of Applied Sciences, 6(6), 1070-1075. doi:10.3844/ajassp.2009.1070.1075

Kadam, S. U., Tiwari, B. K., \& O'Donnell, C. P. (2015). Effect of ultrasound pre-treatment on the drying kinetics of brown seaweed Ascophyllum nodosum. Ultrasonics Sonochemistry, 23, 302-307. doi:10.1016/j.ultsonch.2014.10.001

Kadi, A. (2005). Beberapa Catatan Kehadiran Marga Sargassum di Perairan Indonesia. Oseana, $X X X(4)$, 19-29. Retreived from oseanografi.lipi.go.id/ dokumen/oseana_xxx(4)19-29.pdf

Kurniasih, S. D., Pramesti, R., \& Ridlo, A. (2014). Penentuan Aktivitas Antioksidan Ekstrak Rumput Laut Ulva sp. dari Pantai Krakal-Yogyakarta. Journal of Marine Research, 3(4), 617-626. Retreived from https://ejournal3.undip.ac.id/index.php/jmr/article/ view/11423/11082

Lahsasni, S., Kouhila, M., Mahrouz, M., \& Jaouhari, J. T. (2004). Drying Kinetics of Prickly Pear Fruit (Opuntia ficus indica). Journal of Food Engineering, 61(2), 173179. doi:10.1016/S0260-8774(03)00084-0

Masduqi, A. F., Izzati, M., \& Prihastanti, E. (2014). Efek Metode Pengeringan Terhadap Kandungan Bahan Kimia dalam Rumput Laut. Buletin Anatomi Dan Fisiologi, XXII(I), 1-9. Retreived from https:// ejournal.undip.ac.id/index.php/janafis/article/view/ $7804 / 6397$

Midilli, A., Kucuk, H., \& Yapar, Z. (2002). A New Model for Single-Layer Drying. Drying Technology, 20(7). 15031513. doi:10.1081/DRT-120005864

Norra, I., Aminah, A., \& Suri, R. (2016). Effects of drying methods, solvent extraction and particle size of Malaysian brown seaweed, Sargassum sp. on the total phenolic and free radical scavenging activity. International Food Research Journal, 23(4), 15581563. Retrieved from http://www.ifrj.upm.edu.my/

Onwude, D. I., Hashim, N., Janius, R. B., Nawi, N. M., \& Abdan, K. (2016). Modeling the Thin-Layer Drying of Fruits and Vegetables: A Review. Comprehensive Reviews in Food Science and Food Safety, 15(3), 599-618. doi:10.1111/1541-4337.12196

Prasetyo, D. J., Jatmiko, T. H., Poeloengasih, C. D., \& Kismurtono, M. (2017). Drying Characteristics of Kidney Shape Ganoderma lucidum Drying in Air Circulation System. IOP Conference Series: Earth and Environmental Science, 101(1), 012012. doi:10.1088/1755-1315/101/1/012012

Robic, A., Sassi, J. F., \& Lahaye, M. (2008). Impact of Stabilization Treatments of the Green Seaweed Ulva rotundata (Chlorophyta) on the Extraction Yield, the Physico-chemical and Rheological Properties of Ulvan. Carbohydrate Polymer, 74(3), 344-352. doi:10.1016/j.carbpol.2008.02.020

Suherman, Djaeni, M., Kumoro, A. C., Prabowo, R. A., Rahayu, S., \& Khasanah, S. (2018). Comparison Drying Behavior of Seaweed in Solar, Sun, and Oven Tray Dryer. MATEC Web of Conference ,156, 05007. doi:10.1051/matecconf/20181565007

Tabarsa, M., Rezaei, M., Ramezanpour, Z., \& Waaland, J. R. (2012). Chemical Compositions of the Marine Algae Gracilaria salicornia (Rhodophyta) and Ulva lactuca (Chlorophyta) as a Potential Food Source. Journal of the Science of Food and Agriculture, 92(12), 2500-2506. doi:10.1002/jsfa.5659

Tulek, Y. (2011). Drying Kinetics of Oyster Mushroom (Pleurotus ostreatus) in a Convective Hot Air Dryer. Journal of Agricultural Science and Technology, 13(5), 655-664.

Yaich, H., Garna, H., Bchir, B., Besbes, S., Paquot, M., Richel, A., Blecker, C., \& Attia, H. (2015). Chemical Composition and Functional Properties of Dietary Fibre Extracted by Englyst and Prosky Methods from the Alga Ulva lactuca Collected in Tunisia. Algal Research, 9, 65-73. doi:10.1016/j.algal.2015.02.017 
Yaich, H., Garna, H., Besbes, S., Paquot, M., Blecker, C., \& Attia, H. (2011). Chemical Composition and Functional Properties of Ulva lactuca Seaweed Collected in Tunisia. Food Chemistry, 128(4), 895901. doi:10.1016/j.foodchem.2011.03.114
Zakaria, F. R., Priosoeryanto, B. P., Erniati, \& Sajida. (2017). Karakteristik Nori dari Campuran Rumput Laut Ulva lactuca dan Eucheuma cottonii. Jurnal Pascapanen dan Bioteknologi Kelautan dan Perikanan ,12(1), 23-30. doi:10.15578/ jpbkp.v12i1.336 
JPB Kelautan dan Perikanan Vol. 13 No. 1 Tahun 2018: 1-12 